\title{
Nursing ethics
}




\section{Nursing ethics}

A principle-based approach

Steven D. Edwards 
Steven D. Edwards 1996

All rights reserved. No reproduction, copy or transmission of this publication may be made without written permission.

No paragraph of this publication may be reproduced, copied or transmitted save with written permission or in accordance with the provisions of the Copyright, Designs and Patents Act 1988, or under the terms of any licence permitting limited copying issued by the Copyright Licensing Agency, 90 Tottenham Court Road, London WIP 9HE.

Any person who does any unauthorised act in relation to this publication may be liable to criminal prosecution and civil claims for damages.

First published 1996 by

MACMILLAN PRESS LTD

Houndmils, Basingstoke, Hampshire RG21 6XS

and London

Companies and representatives

throughout the world

ISBN 978-0-333-61590-4 ISBN 978-1-349-13488-5 (eBook) DOI 10.1007/978-1-349-13488-5

A catalogue record for this book is available from the British Library

$\begin{array}{llllllllll}10 & 9 & 8 & 7 & 6 & 5 & 4 & 3 & 2 & 1\end{array}$

$\begin{array}{llllllllll}05 & 04 & 03 & 02 & 01 & 00 & 99 & 98 & 97 & 96\end{array}$ 


\section{Contents}

Preface

vii

Introduction

1 Preliminary matters 3

What is ethics? 3

Why should nurses study ethics?

How can moral issues be identified? 11

2 A principle-based approach to nursing ethics 17

$\begin{array}{ll}\text { The framework and its levels } & 17\end{array}$

Level-four moral theories (i): Utilitarianism 24

Level-four moral theories (ii): a deontological theory 29

The relationships between the levels of the

framework 38

Arguments for the priority of level three of the framework $\quad 44$

Merits of the principle-based approach 49

3 The level-three principles 52

The principle of respect for autonomy 52

$\begin{array}{ll}\text { The principle of beneficence } & 68\end{array}$

$\begin{array}{ll}\text { The principle of nonmaleficence } & 71\end{array}$

$\begin{array}{ll}\text { The principle of justice } & 76\end{array}$

Conclusion $\quad 88$

4 Conflicts between principles 90

Respect for autonomy in conflict with beneficence and nonmaleficence 
vi Contents

Autonomy in conflict with justice: allocation of scarce resources

5 A challenge to the principle-based approach

Concerns about the principle-based approach

A care-based approach

Criticism of the care-based view

A common misconception: care is not the essence of nursing

A defence of a principle-based approach $\quad 140$

A final position

6 The supererogatory nurse

What are supererogatory acts?

To whom do nurses have obligations?

Do nurses undertake supererogatory acts? 


\section{Preface}

I have tried to produce a degree-level text in nursing ethics, but one which will be of use to nursing diploma students, to those studying nursing ethics at postgraduate level, and to registered nurses who are undertaking short courses in nursing ethics. I became aware of the need for such a text between 1991 and 1993. During this period I was required to write and to teach a number of courses in nursing ethics at varying levels. There are, of course, several books on nursing ethics, but none seemed to be at just the right level for the needs of the students I taught. Although many students found Melia (1989) and Chadwick and Tadd (1992) extremely useful introductions to the subject, these texts seemed not to provide material beyond diploma level.

The most thorough treatment of health care ethics that I am aware of is Beauchamp and Childress's Principles of Biomedical Ethics $(1989,1994)$. It is no understatement to reveal that this book changed my whole outlook on nursing ethics and this is evident throughout the following text. The students I taught, however, did not seem to find Beauchamp and Childress userfriendly; they found it too dense and too medically orientated. Hence, it has been my intention to provide a text which approximates the systematicity of Beauchamp and Childress's work, but which is more accessible to students of nursing ethics.

When I trained as a nurse, the curriculum included no ethics whatsoever. Yet, the moral problems encountered during my time in nursing drove me to study philosophy at undergraduate level. It soon became apparent that, at that time (the mideighties), the subject matter of ethics courses made no mention of the kinds of moral problems which arise in nursing practice. Further, I came to realise that the problem of moral knowledge was merely a part of a larger problem of knowledge in general. 
viii Preface

This led me into the problem of philosophical relativism and far away from applied ethics.

A peculiar chain of events resulted in my obtaining a post which involved nothing other than teaching nursing ethics. This gave me the opportunity to re-examine the moral problems which I had faced as a nurse many years earlier, and this book forms part of that ongoing examination.

I have benefited greatly over the years from discussion of moral matters with very many people. But I would like to acknowledge particular debts of gratitude to the 1991 intake of nursing students at Buckinghamshire College of Higher Education, to Ed Lepper and to Simon Woods.

Swansea

STEVEN D. EDWARDS 